OPEN ACCESS

Edited by:

Karl H. Mühling,

University of Kiel, Germany

Reviewed by:

Franz Hippler,

Yara International, Brazil

Vitor L. Nascimento,

Universidade Federal de Lavras, Brazi

Asif Naeem,

Nuclear Institute for Agriculture and Biology, Pakistan

*Correspondence:

Bo-Fang Yan

zansybf@163.com

Matthias Wiggenhauser matthias.wiggenhauser@usys.ethz.ch

†These authors have contributed equally to this work

Specialty section:

This article was submitted to Plant Nutrition,

a section of the journal

Frontiers in Plant Science

Received: 25 June 2021 Accepted: 22 November 2021 Published: 21 December 2021

Citation:

Yan B-F, Dürr-Auster T, Frossard E and Wiggenhauser M (2021) The Use of Stable Zinc Isotope Soil Labeling to Assess the Contribution of Complex Organic Fertilizers to the Zinc Nutrition of Ryegrass.

Front. Plant Sci. 12:730679 doi: 10.3389/fp/s.2021.730679

\section{The Use of Stable Zinc Isotope Soil Labeling to Assess the Contribution of Complex Organic Fertilizers to the Zinc Nutrition of Ryegrass}

\author{
Bo-Fang Yan ${ }^{* \dagger}$, Thilo Dürr-Auster ${ }^{\dagger}$, Emmanuel Frossard and Matthias Wiggenhauser* \\ Department of Environmental Systems Science, Group of Plant Nutrition, ETH Zurich, Lindau, Switzerland
}

Manure and sewage sludge are known to add significant amounts of zinc (Zn) and other metals to soils. However, there is a paucity of information on the fate of $\mathrm{Zn}$ that derives from complex organic fertilizers in soil-plant systems and the contribution of these fertilizers to the Zn nutrition of crops. To answer these questions, we grew Italian ryegrass in the presence of $\mathrm{ZnSO}_{4}$, sewage sludge, and cattle and poultry manure in an acidic soil from Heitenried, Switzerland, and an alkaline soil from Strickhof, Switzerland, where the isotopically exchangeable $\mathrm{Zn}$ had been labeled with ${ }^{67} \mathrm{Zn}$. This allowed us to calculate the fraction of $\mathrm{Zn}$ in the shoots that was derived from fertilizer, soil, and seed over 4 successive cuts. In addition, we measured the ${ }^{67} \mathrm{Zn}:{ }^{66} \mathrm{Zn}$ isotope ratio with the diffusive gradients in thin films technique (DGT) on soils labeled with ${ }^{67} \mathrm{Zn}$ and incubated with the same fertilizers. After 48 days of growth, the largest fraction of $\mathrm{Zn}$ in the ryegrass shoots was derived from the soil (79-88\%), followed by the Zn-containing fertilizer (11-20\%); the least $(<2.3 \%)$ came from the seed. Only a minor fraction of the $\mathrm{Zn}$ applied with the fertilizer was transferred to the shoots $(4.7-12 \%)$, which indicates that most of the freshly added $Z n$ remained in the soil after one crop cycle and may thereby contribute to a residual $\mathrm{Zn}$ pool in the soil. The ${ }^{67} \mathrm{Zn}:{ }^{66} \mathrm{Zn}$ isotope ratios in the DGT extracts and the shoots measured at cut 4 were identical, suggesting that the DGT and plant took up Zn from the same pool. The proportion of Zn derived from the fertilizers in the DGT extracts was also identical to that measured in ryegrass shoots at cut 4 . In conclusion, this work shows that stable $\mathrm{Zn}$ isotope labeling of the soil available $\mathrm{Zn}$ can be used to precisely quantify the impact of complex organic fertilizers on the Zn nutrition of crops. It also demonstrates that DGT extractions on labeled soils could be used to estimate the contribution of $\mathrm{Zn}$ fertilizers to plant nutrition.

Keywords: manure, sewage sludge, plant nutrition, source tracing, DGT (diffusive gradients in thin films)

\section{INTRODUCTION}

Complex organic fertilizers such as sewage sludge, animal manure, and compost are known sources of heavy metals such as zinc ( $\mathrm{Zn}$ ) in agroecosystems (Nicholson et al., 2003; Imseng et al., 2019). Bolan et al. (2004) reported that the concentration of $\mathrm{Zn}$ in animal manure and sewage sludge ranged from 1.8 to $6480 \mathrm{mg} \mathrm{kg}^{-1}$ (median $378 \mathrm{mg} \mathrm{kg}^{-1}$ ). Tella et al. (2016) and 
Hodomihou et al. (2020) reported that Zn was mainly present as inorganic species in organic fertilizers, including $\mathrm{Zn}$ adsorbed on iron oxides and amorphous $\mathrm{Zn}$-phosphate. Some of these $\mathrm{Zn}$ species can contribute directly to the pool of soil $\mathrm{Zn}$ available and be taken up by crops. Complex organic fertilizers can also increase soil $\mathrm{Zn}$ availability through the inputs of carbon (C), nitrogen $(\mathrm{N})$, or other elements and thereby raise $\mathrm{Zn}$ uptake by plants (Aghili et al., 2014). These authors demonstrated that the application of plant residues labeled with ${ }^{65} \mathrm{Zn}$ strongly enhanced the uptake of $\mathrm{Zn}$ derived from the soil (non-labeled) by wheat. An increased solubility of soil $\mathrm{Zn}$ may be caused by nitrification of ammonium added with the organic fertilizer, which leads to acidification, and also by the decomposition of organic compounds leading to the release of water-soluble organic compounds that can form complexes with soil $\mathrm{Zn}$ (Gramlich et al., 2013; Soltani et al., 2014). Meanwhile, mineral nutrients and $\mathrm{C}$ inputs into soils may also promote plant uptake of $\mathrm{Zn}$ by favoring plant growth or improving soil structure, which allows better soil exploration by roots (Mäder et al., 2002; Alloway, 2009). To date, the effect of organic fertilizers on the plant uptake of soil $\mathrm{Zn}$, and their contribution to $\mathrm{Zn}$ uptake by plants through $\mathrm{Zn}$ supply, has been quantified only for fresh plant residues (Aghili et al., 2014) but not yet for animal manure or sewage sludge.

The amount of $\mathrm{Zn}$ derived from a fertilizer that is taken up by a plant can be estimated by calculating its "apparent use efficiency" (AUE). AUE is the difference between the amount of $\mathrm{Zn}$ taken up by a plant that has been fertilized with $\mathrm{Zn}$ and the amount of $\mathrm{Zn}$ taken by the same plant grown in the absence of $\mathrm{Zn}$ fertilizer, divided by the amount of $\mathrm{Zn}$ added as fertilizer. Using this mass balance approach, Berenguer et al. (2008) estimated that 9-22\% of the $\mathrm{Zn}$ added by liquid swine manure was taken up by maize plants in the year following the input. However, this approach rests on the implicit hypothesis that $\mathrm{Zn}$ derived from the soil is independent from the fertilizer addition (Schindler and Knighton, 1999). In other words, the AUE approach ignores the aforementioned effects of organic fertilizers on the solubility of $\mathrm{Zn}$ in the soil. To determine the fate of freshly applied $\mathrm{Zn}$, therefore, the plant uptake of $\mathrm{Zn}$ derived from organic fertilizer and soil needs to be distinguished, which can be precisely done using $\mathrm{Zn}$ isotopes.

Quantifying the amount of $\mathrm{Zn}$ taken up by a plant from freshly applied fertilizer or soil can be achieved using isotopic approaches whereby either the fertilizer $\mathrm{Zn}$ or the soil available $\mathrm{Zn}$ is isotopically labeled. Whereas water soluble $\mathrm{Zn}$ or plant residues can be easily labeled homogeneously with radioactive or stable $\mathrm{Zn}$ isotopes, it is very difficult to do this with animal manure and sewage sludge, since they comprise mixtures of different inorganic and organic $\mathrm{Zn}$ phases (Bosshard et al., 2011; Hodomihou et al., 2020). Instead of labeling the fertilizer, it is possible to label the soil available $\mathrm{Zn}$ and calculate the amount of $\mathrm{Zn}$ derived from soil, fertilizer, and seed by analyzing the isotope ratio of $\mathrm{Zn}$ taken up by plants, for example, as done for phosphorus (P) by measuring the decrease of P-specific activity in plants (Pypers et al., 2006; Frossard et al., 2011). A recent methodological study has been shown that labeling soils with the stable isotope ${ }^{67} \mathrm{Zn}$ can be used to assess the plant uptake of $\mathrm{Zn}$ derived from wheat straw compost (Dürr-Auster et al., 2019). This requires that the isotope ratios of ${ }^{67} \mathrm{Zn}:{ }^{66} \mathrm{Zn}$ can be adequately resolved which was achieved using a quadrupole single-collector (Q-)ICP-MS. Hence, labeling the pool of soil exchangeable $\mathrm{Zn}$ with ${ }^{67} \mathrm{Zn}$ could be used to quantify the plant uptake of $\mathrm{Zn}$ derived from the soil and from sewage sludge or animal manure. Moreover, the isotope label can be used to calculate the recovery of the $\mathrm{Zn}$ applied with the fertilizer in the plant. Such recovery calculations can provide valuable insights about the potential fate of $\mathrm{Zn}$ in soil-plant systems after harvest (McBeath et al., 2013; Bracher et al., 2021; Mattiello et al., 2021).

The diffusive gradients in thin films technique (DGT) is a wellestablished tool to predict the plant available pool of $\mathrm{Zn}$ in the soil. A strong correlation between the amount of $\mathrm{Zn}$ extracted by the DGT sampler and the concentration of $\mathrm{Zn}$ in plant tissues has been shown in several studies (e.g., Degryse et al., 2009; Tandy et al., 2011). By measuring the isotopic composition of DGT extract in fertilized soils labeled with $\mathrm{Zn}$ isotope, it should be possible to identify the contribution of different sources (soil, fertilizer) in the available $\mathrm{Zn}$ pool independently from the effect of the plants (e.g., dry matter production, root exudates, seed $\mathrm{Zn}$, etc.). However, this type of analysis has not yet been done for $\mathrm{Zn}$.

The objectives of this study were to (1) precisely quantify the amount of $\mathrm{Zn}$ in plants derived from fertilizer, soil, and seeds in soils amended with distinct complex organic fertilizers, (2) determine the fate of $\mathrm{Zn}$ input with complex organic fertilizer in soil-plant systems, and (3) test whether DGT can be employed to predict the relative contribution of soil and fertilizer sources to the plant uptake of $\mathrm{Zn}$. To this end, two cropped soils, an acidic soil from Heitenried, Switzerland, and an alkaline soil from Strickhof, Switzerland, were labeled with ${ }^{67} \mathrm{Zn}$. Italian ryegrass (Lolium multiflorum, var. Gemini) was grown as a model plant that takes up most of its $\mathrm{Zn}$ from the soil isotopically exchangeable pool (Sinaj et al., 2004). Besides a control that received no $\mathrm{Zn}$, water-soluble $\mathrm{ZnSO}_{4}$, sewage sludge, poultry manure, and cattle manure were applied. These fertilizers brought similar amounts of $\mathrm{Zn}$ but different amounts of $\mathrm{N}$ and $\mathrm{C}$ to the soils.

\section{MATERIALS AND METHODS}

\section{Soils and Zinc Fertilization}

The soils were collected, and the isotopically exchangeable $\mathrm{Zn}$ was labeled according to the procedure described in Dürr-Auster et al. (2019). Briefly, the arable layer of two soils (0-20 cm depth) was sampled from Heitenried and Strickhof, both in Switzerland. These two soils were selected based on their distinct $\mathrm{pH}$, since this property is a major factor affecting the solubility of soil $\mathrm{Zn}$ and plant Zn uptake (Mertens and Smolders, 2013). Both soils were percolated with a nutrient solution containing ${ }^{67} \mathrm{Zn}$-enriched isotope ( ${ }^{67} \mathrm{Zn}$ abundance $=32 \%$ ) used in a wheat growth trial (Signorell et al., 2019) for 20 weeks. Then, they were mixed, sieved to $7 \mathrm{~mm}$ aggregate size, air-dried, and stored in dark and dry conditions at room temperature for 1 year before being used for the experiments presented here. The properties of the soil after the labeling procedure are summarized in Table $\mathbf{1 .}$ 
TABLE 1 | Selected soil properties after the labeling procedure.

\begin{tabular}{|c|c|c|c|c|c|c|c|}
\hline \multirow[t]{2}{*}{ Origina } & \multirow[t]{2}{*}{ Soil type ${ }^{b, *}$} & \multirow[t]{2}{*}{ Texture } & \multirow[t]{2}{*}{$\mathrm{pH}^{*}\left(\mathrm{H}_{2} \mathrm{O}^{\mathrm{c}}\right)$} & \multirow{2}{*}{$\frac{\left.\text { Total Zn* (EDXRF }{ }^{\mathrm{d}}\right)}{\mathrm{mg} \mathrm{Zn} \mathrm{kg}^{-1} \mathrm{DM}^{\mathrm{g}} \text { soil }}$} & \multirow{2}{*}{$\frac{\text { DTPA }^{\mathrm{e}} \text {-extractable } \mathrm{Zn}^{*}}{\mathrm{mg} \mathrm{Zn} \mathrm{kg}{ }^{-1} \text { DM soil }}$} & \multirow{2}{*}{$\frac{\text { Water-holding capacity }{ }^{\mathrm{f}, *}}{\mathrm{~g} \mathrm{H}_{2} \mathrm{O} \mathbf{k g}^{-1} \text { DM soil }}$} & \multirow{2}{*}{$\frac{\mathrm{CaCO}_{3}}{\mathrm{~g} \mathrm{~kg}^{-1} \mathrm{DM} \text { soil }}$} \\
\hline & & & & & & & \\
\hline Heitenried & Fluvisol & Sandy loam & 4.9 & 54.1 & 4.1 & 387 & 0 \\
\hline Strickhof & Cambisol & Loam & 7.7 & 101.1 & 5.2 & 447 & 36.7 \\
\hline
\end{tabular}

*Data were published in Dürr-Auster et al. (2019).

${ }^{a}$ Collected from a depth of $0-20 \mathrm{~cm}$.

${ }^{b}$ According to the International Union of Soil Sciences (IUSS) Working Group World Reference Base for Soil Resources (IUSS Working Group WRB, 2015).

${ }^{c} \mathrm{pH}$ in $\mathrm{H}_{2} \mathrm{O}$ with $1 / 2.5(\mathrm{~m} / \mathrm{v})$ solid/liquid ratio.

${ }^{d}$ Energy dispersive $X$-ray fluorescence spectrometry.

${ }^{e}$ Diethylenetriaminepentaacetic acid.

${ }^{f}$ Maximal soil saturation with $\mathrm{H}_{2} \mathrm{O}$ without external pressure.

$g$ Dry matter

The dried sewage sludge was obtained from the wastewater treatment facility of the city of Zurich, Switzerland (https://www. stadt-zuerich.ch/ted/de/index/entsorgung_recycling/sauberes_ wasser/klaerwerk.html). Poultry manure and cattle manure in the form of dried pellets were bought from the Landi farmers' shop (https://www.landi.ch). These organic fertilizers were finely ground before their application. Mineral $\mathrm{Zn}$ fertilizer was supplied as a $\mathrm{ZnSO}_{4}$ solution. These $\mathrm{Zn}$-containing fertilizers were thoroughly mixed with each labeled soil. The application rate was based on the $\mathrm{Zn}$ concentration of the fertilizer, leading to similar amounts of $\mathrm{Zn}$ added per kilogram of soil (i.e., $\mathrm{Zn}$ input) but different $\mathrm{N}$ and $\mathrm{C}$ inputs among these treatments (Table 2). A control treatment that received no $\mathrm{Zn}$ was also established.

\section{Plant Growth Trial}

The plant growing conditions were similar to those described in Dürr-Auster et al. (2019). Briefly, pots containing $400 \mathrm{~g}$ labeled dry soil with or without the addition of the abovementioned $\mathrm{Zn}$ containing fertilizers were watered to $40 \%$ water-holding capacity and placed randomly in a growth chamber ( $14 \mathrm{~h}$ day-light at 25 $\mathrm{klx}$, day-night temperature $24-18^{\circ} \mathrm{C}$, and relative atmospheric humidity $60-65 \%)$. Then $500 \mathrm{mg}$ of Italian ryegrass seeds $(35.2$ $\mu \mathrm{g} \mathrm{Zn} \mathrm{g}^{-1}$ seed) was sown in each pot. As observed in our previous isotope labeling studies on phosphorus and $\mathrm{Zn}$, the root system of ryegrass can colonize well in a pot with a relatively small volume of soil over a short growth time, which is a prerequisite so that the plant shoots can provide a proper estimation of the isotopic signature of the available P and $\mathrm{Zn}$ (Sinaj et al., 2004; Frossard et al., 2014). Ten days after sowing, a nutrient solution was applied at a rate of $506 \mathrm{mg} \mathrm{N} \mathrm{kg}^{-1}$ soil (ammonium nitrate), $55 \mathrm{mg} \mathrm{P} \mathrm{kg}{ }^{-1}$ soil (phosphate), $138 \mathrm{mg} \mathrm{K} \mathrm{kg}^{-1}$ soil $\left(\mathrm{K}^{+}\right), 31 \mathrm{mg}$ $\mathrm{S} \mathrm{kg}^{-1}$ soil (sulfate), $23 \mathrm{mg} \mathrm{Mg} \mathrm{kg}{ }^{-1}$ soil $\left(\mathrm{Mg}^{2+}\right), 5 \mathrm{mg} \mathrm{Fe} \mathrm{kg}-1$ soil (Fe-EDTA), $232 \mu \mathrm{g} \mathrm{B} \mathrm{kg}{ }^{-1}$ soil (boric acid), $127 \mu \mathrm{g} \mathrm{Mn}$ $\mathrm{kg}^{-1}$ soil $\left(\mathrm{Mn}^{2+}\right), 31 \mu \mathrm{g} \mathrm{Cu} \mathrm{kg}{ }^{-1}$ soil $\left(\mathrm{Cu}^{2+}\right)$, and $54 \mu \mathrm{g} \mathrm{Mo}$ $\mathrm{kg}^{-1}$ soil (molybdic acid). Distilled water was supplied regularly to the pot by weighing to maintain soil moisture between 40 and $80 \%$ water-holding capacity. No drought symptoms were observed on the ryegrass plants throughout the experiment. Each treatment had 4 replicates with 1 pot per replicate. These pots were randomly rearranged after each watering. The shoots were harvested 4 times by cutting at 21,30, 38, and 48 days after sowing, to minimize the influence of seed $\mathrm{Zn}$ on the tracing of fertilizer $\mathrm{Zn}$. After each cut, the nutrient solution was resupplied at a rate of $20 \%$ of the first load.

\section{Incubation Experiment}

A soil incubation experiment was carried out in parallel with the growth trial for deploying the DGT sampler to extract Zn from the soil available $\mathrm{Zn}$ pool. To this end, one pot per treatment was prepared for each type of soil, but no ryegrass was grown. The pot received only the first load of the abovementioned nutrient solution and was then placed in the same growth chamber as the growth trial. Distilled water was supplied weekly to adjust the soil moisture at $80 \%$ water-holding capacity to keep the soil moisture in the same range as for the plant trial. The soil incubation lasted until the fourth cut of the ryegrass (i.e., 48 days).

After the incubation, 4 beakers, each containing about $50 \mathrm{~g}$ of incubated soils (dry weight equivalent), were prepared for each incubated pot, to make 4 replicates. Following the protocol described in Hooda et al. (1999), the soils were watered to $100 \%$ water-holding capacity and equilibrated in an incubator at $24^{\circ} \mathrm{C}$ for $24 \mathrm{~h}$. After that, the DGT sampler (DGT Research Ltd, Lancaster, UK) was deployed onto the soil surface and incubated at $24^{\circ} \mathrm{C}$ for $72 \mathrm{~h}$. Then the DGT sampler was dismantled to remove the resin, from which $\mathrm{Zn}$ was eluted with $1 \mathrm{ml}$ of $1 \mathrm{M}$ $\mathrm{HNO}_{3}$ for $24 \mathrm{~h}$ (i.e., DGT extracts).

\section{Sampling and Analyses}

At each cut, the ryegrass shoots were oven-dried at $65^{\circ} \mathrm{C}$ for $48 \mathrm{~h}$, weighed, and ground using a bead mill equipped with tungsten carbide cups. Subsamples of the plant material were then digested with $4 \mathrm{ml}$ of $8 \mathrm{M} \mathrm{HNO}_{3}$ in a high-pressure single-reaction microwave chamber (turboWave, MWS GmbH, Heerbrugg, Switzerland). The same digestion was applied to the dried fertilizers. An aliquot of the digest was purified to extract $\mathrm{Zn}$ from the sample matrix. Sample purification was shown to be necessary for $\mathrm{Zn}$ isotope analysis with quadrupole single-collector (Q-)ICP-MS in stable $\mathrm{Zn}$ isotope soil labeling experiments (Dürr-Auster et al., 2019). A detailed protocol on the separation of $\mathrm{Zn}$ from the sample matrix using ion exchange chromatography is provided in Dürr-Auster et al. (2019). In this study, the protocol was applied for plant digests and DGT extracts. The concentration of total $\mathrm{Zn}$ was determined for 
TABLE 2 | Total Zn concentration in the studied fertilizers and the input of total Zn, N, and C to soil with the application of each fertilizer.

\begin{tabular}{|c|c|c|c|c|}
\hline \multirow[t]{2}{*}{ Treatment } & Zn concentration in fertilizers ${ }^{a}$ & Zn input with fertilization & $\mathbf{N}$ input with fertilization $\mathbf{b}$ & C input with fertilization ${ }^{b}$ \\
\hline & $\mathbf{m g ~ Z n ~} \mathbf{k g}^{-1}$ fertilizer & 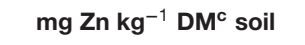 & mg N kg-1 DM soil & mg C kg ${ }^{-1} \mathrm{DM}$ soil \\
\hline No Zn & 0 & 0 & 0 & 0 \\
\hline $\mathrm{ZnSO}_{4}^{\mathrm{d}}$ & $440 \times 10^{3}$ & 1.42 & 0 & 0 \\
\hline Sewage sludge ${ }^{e}$ & 634 & 1.52 & 90 & $0.734 \times 10^{3}$ \\
\hline Poultry manure & 443 & 1.51 & 88 & $1.090 \times 10^{3}$ \\
\hline Cattle manure $^{\mathrm{e}}$ & 353 & 1.56 & 225 & $1.704 \times 10^{3}$ \\
\hline
\end{tabular}

a Measured in $\mathrm{HNO}_{3}$ microwave digested fertilizers (Dürr-Auster et al., 2019).

${ }^{b}$ Determined through CN elemental analysis (Thermo Scientific Flash EA 1112).

${ }^{c}$ Dry matter.

${ }^{a}$ Applied as water solution.

${ }^{\text {e}}$ Applied as dried powder.

the plant and the fertilizer digests by ICP-OES (ICPE-9820 Series, Shimadzu, Kyoto, Japan). The ${ }^{67} \mathrm{Zn}:{ }^{66} \mathrm{Zn}$ isotope ratio was determined using (Q-)ICP-MS (7500ce, Agilent Technologies, Santa Clara, California, USA) for the purified samples and corrected for mass bias using standard sample bracketing, as explained in Dürr-Auster et al. (2019).

\section{Data Processing and Analysis}

For each cut of each pot, the Zn uptake in the ryegrass shoots at cut $i\left[Z n_{\mathrm{i}}\left(\mu \mathrm{g} \mathrm{kg}^{-1}\right.\right.$ soil), with $i$ varying from 1 to 4$]$ was obtained from the $\mathrm{Zn}$ concentration $\left[C Z n_{\mathrm{i}}\left(\mu \mathrm{g} \mathrm{g} \mathrm{g}^{-1} \mathrm{DW}\right)\right]$ and the dry weight $\left[D W_{\mathrm{i}}\left(\mathrm{g} \mathrm{kg}^{-1}\right.\right.$ soil $\left.)\right]$ of the corresponding cut:

$$
Q Z n_{i}=C Z n_{\mathrm{i}} \times D W_{\mathrm{i}}
$$

$\mathrm{QZ} n_{\mathrm{i}}$ was normalized to $1 \mathrm{~kg}$ of soil to describe the transfer of $\mathrm{Zn}$ from the soil. The values of $D W_{\mathrm{i}}, C Z n_{\mathrm{i}}$, and $Q Z n_{\mathrm{i}}$ in the ryegrass shoot at each cut are shown in Supplementary Table S1.

$Q Z n_{\mathrm{i}}$ was composed of the uptake of $\mathrm{Zn}$ derived from the fertilizer [QZndffert $t_{\mathrm{i}}\left(\mu \mathrm{g} \mathrm{kg}^{-1}\right.$ soil)], soil [QZndfsoil $\mathrm{i}_{\mathrm{i}}\left(\mu \mathrm{g} \mathrm{kg}^{-1}\right.$ soil)], and seeds [QZndfseed ${ }_{\mathrm{i}}\left(\mu \mathrm{g} \mathrm{kg}^{-1}\right.$ soil)]:

$$
Q Z n_{i}=Q_{n} \text { dffert } t_{\mathrm{i}}+Q Z n d f \text { soil }_{\mathrm{i}}+\mathrm{QZndfseed}_{\mathrm{i}}
$$

In the ryegrass shoot, the relative proportion of $\mathrm{Zn}$ derived from the fertilizer [Zndffert $\left.t_{\mathrm{i}}(\%)\right]$, soil [Zndfsoil $\left.l_{\mathrm{i}}(\%)\right]$, and seed [Zndfseed $(\%)$ ] add up to $100 \%$ :

$$
100 \%=Z_{n d f f e r t}+Z n d f_{\mathrm{i} o i l_{\mathrm{i}}}+Z_{\text {ndfseed }}
$$

The isotopically exchangeable $\mathrm{Zn}$ in the soils was labeled with ${ }^{67} \mathrm{Zn}$ isotope, and therefore, it had a higher ${ }^{67} \mathrm{Zn}:{ }^{66} \mathrm{Zn}$ ratio than the $\mathrm{Zn}$ derived from the fertilizers and seeds. As shown in Supplementary Figure S1, the isotope ratios of ${ }^{67} \mathrm{Zn}:{ }^{66} \mathrm{Zn}$ were in all treatments lower at cut 1 than at the other cuts. In the no $\mathrm{Zn}$ treatment, $\mathrm{Zn}$ in the shoot was derived solely from the soil or the seed, where the soil was labeled with ${ }^{67} \mathrm{Zn}$ (high ${ }^{67} \mathrm{Zn}:{ }^{66} \mathrm{Zn}$ isotope ratio) and the seed was not labeled (low ${ }^{67} \mathrm{Zn}:{ }^{66} \mathrm{Zn}$ isotope ratio). Hence, the lower ${ }^{67} \mathrm{Zn}:{ }^{66} \mathrm{Zn}$ isotope ratios in the shoots at the 1 compared with cuts $2-4$ can only derive from a higher contribution of seed $\mathrm{Zn}$ to the plant shoot at cut 1 compared with cuts $2-4$. For the treatments applied with the $\mathrm{Zn}$-containing fertilizers, the differences between cut 1 and the other cuts were similar to the no $\mathrm{Zn}$ treatment. Meanwhile, no significant differences were observed among cuts 2, 3, and 4, regardless of the soils or treatments. Taken together, these results suggest that QZndfseed was only significant in cut 1 and was the same among treatments in each soil.

For the no Zn treatment, only two sources of Zn existed, which were soil $\mathrm{Zn}$ and seed $\mathrm{Zn}$. Therefore, $\mathrm{Zndfseed}$ was calculated for each soil on cut 1 of the no $\mathrm{Zn}$ treatment as follows [equation adapted from McBeath et al. (2013)]:

$$
\begin{aligned}
& Z \text { Zndfseed } \\
& =\frac{{ }^{66} Z n_{\text {soil }} \cdot R_{1 \_ \text {noZn }}-{ }^{67} Z n_{\text {soil }}}{\left({ }^{67} Z n_{\text {seed }}-{ }^{67} Z n_{\text {soil }}\right)-R_{1 \_n o Z n} \cdot\left({ }^{66} Z n_{\text {seed }}-{ }^{66} Z n_{\text {soil }}\right)} \times 100 \%
\end{aligned}
$$

Where $R_{1 \_n o Z n}$ refers to the ${ }^{67} \mathrm{Zn}:{ }^{66} \mathrm{Zn}$ (mole mole ${ }^{-1}$ ) ratio measured in the shoot of cut 1 of the no $\mathrm{Zn}$ treatment, ${ }^{66} \mathrm{Zn}$ and ${ }^{67} \mathrm{Zn}$ refer to the mole fraction of the corresponding isotope (i.e., isotope abundance), whereas the subscript soil and seed designate values of $\mathrm{Zn}$ isotope abundance of the soil and the seed, respectively. $Z n_{\text {soil }}$ was provided by the shoot at cut 4 of the no $\mathrm{Zn}$ treatment. With the successive cuts, seed $\mathrm{Zn}$, if any was left after cut 1 , could be continuously translocated to the shoots. Therefore, the more cuts were carried out, the less seed $\mathrm{Zn}$ would be left in the soil. The last cut (i.e., cut 4) was used to ensure that the seed $\mathrm{Zn}$ was largely exhausted through the previous 3 cuts. $Z n_{\text {seed }}$ was assumed to be a natural isotope composition (Meija et al., 2016).

For the fertilized treatments, the proportion of $\mathrm{Zn}$ derived from the fertilizer and seed $\left(Z n d f[\text { fert }+ \text { seed }]_{\mathrm{i}}[\%]\right)$ at cut $i$ was calculated, and $Z n d f_{\text {soil }}$ was then obtained:

$$
\begin{aligned}
& Z n d f[\text { fert }+ \text { seed }]_{\mathrm{i}} \\
& =\frac{{ }^{66} Z n_{\text {soil }} \cdot R_{\mathrm{i}}-{ }^{67} Z n_{\text {soil }}}{\left({ }^{67} Z n_{\text {fert }}-{ }^{67} Z n_{\text {soil }}\right)-R_{\mathrm{i}} \cdot\left({ }^{66} Z n_{\text {fert }}-{ }^{66} Z n_{\text {soil }}\right)} \times 100 \% \\
& Z n d f \text { soil } l_{\mathrm{i}}=100 \%-Z n d f[\text { fert }+ \text { seed }]_{\mathrm{i}}
\end{aligned}
$$

Where $R_{\mathrm{i}}$ refers to ${ }^{67} \mathrm{Zn}:{ }^{66} \mathrm{Zn}$ (mole mole ${ }^{-1}$ ) measured in the shoot at cut $i$ and the subscript fert designates values 
of $\mathrm{Zn}$ isotope abundance of the fertilizer, which was deemed to be not distinguishable from the values of seed $\mathrm{Zn}$. The isotope compositions of $Z n_{\text {fert }}, Z n_{\text {soil }}$, and $Z n_{\text {seed }}$ are shown in Supplementary Table S2.

For each soil, QZndfseed was calculated from the uptake of $\mathrm{Zn}$ at cut 1 of the no $Z n$ treatment $\left(Q Z n_{1} \_\right.$noZn $)$. QZndffert ${ }_{1}$ was then corrected for seed $\mathrm{Zn}$ with the mean value of QZndfseed in the same soil:

$$
\begin{aligned}
& \text { QZndfseed }=Q Z n_{1 \_ \text {noZn }} \times Z n d f \text { seed } \\
& \text { QZndffert }_{1}=Q Z n_{1} \times Z n d f[\text { fert }+ \text { seed }]_{1}-\overline{Q Z n d f s e e d}
\end{aligned}
$$

$Z_{\text {ndffert }}$ was calculated from QZndffert ${ }_{1}$, while Zndffert $_{2-4}$ were hypothesized to be equal to $Z n d f[\text { fert }+ \text { seed }]_{2-4}$ :

$$
\begin{aligned}
\text { Zndffert }_{1} & =\left(\text { QZndffert }_{1} / \mathrm{QZn}_{1}\right) \times 100 \% \\
\text { Zndffert }_{2-4} & =\text { Zndf }[\text { fert }+ \text { seed }]_{2-4}
\end{aligned}
$$

The values of $Z n d f f e r t_{i}$ and $Z n d f$ soil $_{\mathrm{i}}$ in the ryegrass shoot at each cut and Zndfseed at cut 1 and cuts 2-4 are shown in Supplementary Table S3.

QZndffert $t_{\mathrm{i}}$ and $Q Z n d f$ soil $_{\mathrm{i}}$ in the ryegrass shoots at cut $i$ were then calculated:

$$
\begin{aligned}
& \text { QZndffert }_{\mathrm{i}}=Q Z n_{\mathrm{i}} \times Z_{\text {ndffert }} \\
& \text { QZndfsoil }_{\mathrm{i}}=Q Z n_{\mathrm{i}} \times Z_{\text {indfsoil }}
\end{aligned}
$$

The values of QZndfseed, QZndffert $t_{\mathrm{i}}$, and QZndfsoil $\mathrm{i}_{\mathrm{i}}$ in the ryegrass shoot at each cut are shown in Supplementary Table S4.

The recovery of $\mathrm{Zn}$ from the fertilizer $\left[\mathrm{ZnRec}_{\mathrm{i}}(\%)\right]$ in the ryegrass shoot at cut $i$ was calculated using:

$$
Z_{n R e c_{\mathrm{i}}}=\left(Q Z n d f f e r t_{\mathrm{i}} / Q Z n_{\text {input }}\right) \times 100 \%
$$

Where $Q Z n_{\text {input }}$ is the input of $\mathrm{Zn}$ into the soil with the $\mathrm{Zn}$ containing fertilizers (Table 2). The values of $Z n R e c_{i}$ in the ryegrass shoot at each cut are shown in Supplementary Table S5.

In this paper, the total dry weight $\left[D W_{\text {sum }}\left(\mathrm{g} \mathrm{kg}^{-1}\right.\right.$ soil)], total $\mathrm{Zn}$ uptake $\left[Q Z n_{\text {sum }}\left(\mu \mathrm{g} \mathrm{kg}{ }^{-1}\right.\right.$ soil)], and averaged $\mathrm{Zn}$ concentration $\left[C Z n_{\text {avg }}\left(\mu \mathrm{gg}^{-1} \mathrm{DW}\right)\right]$ in the ryegrass shoots of the 4 cuts are discussed. They were calculated for each pot, as follows:

$$
\begin{aligned}
D W_{\text {sum }} & =D W_{1}+D W_{2}+D W_{3}+D W_{4} \\
Q Z n_{\text {sum }} & =Q Z n_{1}+Q Z n_{2}+Q Z n_{3}+Q Z n_{4} \\
C Z n_{\text {avg }} & =\left(C Z n_{1}+C Z n_{2}+C Z n_{3}+C Z n_{4}\right) / 4
\end{aligned}
$$

Then, the total uptake and averaged proportion of $\mathrm{Zn}$ derived from the fertilizer [QZndffert sum $_{(}\left(\mu \mathrm{g} \mathrm{kg}^{-1}\right.$ soil); Zndffert $\left.t_{\mathrm{avg}}(\%)\right]$ and the soil [QZndfsoil sum $_{(}\left(\mu \mathrm{g} \mathrm{kg}^{-1}\right.$ soil); Zndfsoil $\left.l_{\mathrm{avg}}(\%)\right]$ of the
4 cuts were calculated:

$$
\begin{aligned}
\text { QZndffert }_{\text {sum }}= & \text { QZndffert }_{1}+\text { QZndffert }_{2}+\text { QZndffert }_{3} \\
& + \text { QZndffert }_{4} \\
\text { QZndfsoil }_{\text {sum }}= & \text { QZndfsoil }_{1}+\text { QZndfsoil }_{2}+\text { QZndfsoil }_{3} \\
& + \text { QZndfsoil }_{4} \\
\text { Zndffert }_{\mathrm{avg}}= & \left(\text { Zndffert }_{1}+\text { Zndffert }_{2}+\text { Zndffert }_{3}\right. \\
& \left.+ \text { Zndffert }_{4}\right) / 4 \\
\text { Zndfsoil }_{\mathrm{avg}}= & \left(\text { Zndfsoil }_{1}+\text { Zndfsoil }_{2}+\text { Zndfsoil }_{3}\right. \\
& \left.+ \text { Zndfsoil }_{4}\right) / 4
\end{aligned}
$$

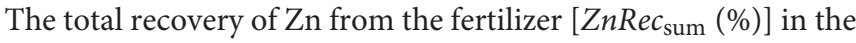
ryegrass shoot at cuts $1-4$ was calculated:

$$
Z_{n R e} \text { sum }=\left(Q Z n d f f e r t_{\text {sum }} / Q Z n_{\text {input }}\right) \times 100 \%
$$

The apparent fertilizer use efficiency [AUE (\%)] was also calculated to compare the results to $Z n R e c_{\text {sum }}$, which relies only on the relative increase of $Q Z n_{\text {sum }}$ resulting from the addition of $\mathrm{Zn}$ with the fertilizer:

$$
A U E=\frac{Q Z n_{\text {sum_fert }}-\overline{Q Z n}_{\text {sum_noZn }}}{Q Z n_{\text {input }}} \times 100 \%
$$

Where $Q Z n_{\text {sum_fert }}$ and $Q Z n_{\text {sum_noZn }}$ are respectively the $Z n$ uptake in the ryegrass shoots $\left(Q Z n_{\text {sum }}\right)$ with and without $Z n$ fertilization in the same soil. For $Q Z n_{\text {sum_noZn }}$, the mean value of the replicates was used.

\section{Statistical Analysis}

Data were processed using $\mathrm{R} \quad 3.6 .3$ statistical software. Identification of significant differences among treatments in the plant growth trial was performed with analysis of variance (ANOVA) and Tukey's honest significant difference post hoc multiple comparison. Two-way ANOVA was performed to test the significance of soil effects, fertilizer effects, and their interaction in the plant growth trial. The Bland-Altman approach was used to compare the $\mathrm{Zn}$ recovery calculated with stable isotope technique and the AUE method and, to compare the ${ }^{67} \mathrm{Zn}:{ }^{66} \mathrm{Zn}$ isotope ratios, and also the proportion of $\mathrm{Zn}$ derived from the fertilizers, measured with the DGT extracts and the plants. This approach allows agreements or discrepancies between two analytical methods to be assessed by illustrating the bias and $95 \%$ confidence interval of the absolute difference between the values obtained by the two methods (Bland and Altman, 1986).

\section{RESULTS}

\section{Plant Growth and Zn Accumulation}

The addition of complex organic fertilizers to the two soils had distinct effects on shoot dry weight, $\mathrm{Zn}$ concentration, and $\mathrm{Zn}$ uptake (Table 3). In the Heitenried soil, the addition of organic fertilizers had no impact on shoot $\mathrm{Zn}$ concentrations. However, the shoot dry weight and $\mathrm{Zn}$ uptake increased by up to factor 1.2 with the addition of poultry manure, compared with those 
TABLE 3 | Total dry weight (DW), averaged Zn concentration, total Zn uptake, and averaged proportion of Zn derived from the Zn-containing fertilizers (Zndffertavg \%) in the Italian ryegrass shoot (sum of 4 cuts) cultivated in a growth chamber and grown in Heitenried soil $(\mathrm{pH}=4.9)$ and Strickhof soil (pH $=7.7)$ amended with distinct Zn-containing fertilizers.

\begin{tabular}{|c|c|c|c|c|c|}
\hline \multirow[t]{2}{*}{ Soil } & \multirow[t]{2}{*}{ Treatment } & \multirow{2}{*}{$\begin{array}{c}\text { Shoot dry weight } \\
\text { g DW kg soil }\end{array}$} & \multirow{2}{*}{ 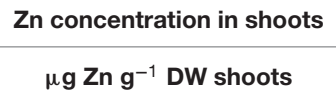 } & \multirow{2}{*}{$\begin{array}{c}\text { Zn uptake in shoots } \\
\mu \mathrm{g} \mathrm{Zn} \mathrm{kg}{ }^{1} \text { soil }\end{array}$} & \multirow{2}{*}{$\frac{\text { Zndffert }}{\text { avg }}$} \\
\hline & & & & & \\
\hline \multirow[t]{5}{*}{ Heitenried } & No Zn & $13.1 \pm 1.9 a$ & $54.9 \pm 1.6 \mathrm{a}$ & $719 \pm 99 a$ & - \\
\hline & $\mathrm{ZnSO}_{4}$ & $14.6 \pm 0.6 a b$ & $56.4 \pm 1.0 \mathrm{a}$ & $816 \pm 29 a b$ & $16.9 \pm 0.8 \mathrm{a}$ \\
\hline & Sewage sludge & $15.1 \pm 0.9 \mathrm{ab}$ & $56.3 \pm 0.8 a$ & $833 \pm 50 a b$ & $19.8 \pm 0.4 b$ \\
\hline & Poultry manure & $15.9 \pm 0.9 b$ & $54.5 \pm 2.1 \mathrm{a}$ & $865 \pm 32 b$ & $20.2 \pm 0.6 \mathrm{~b}$ \\
\hline & Cattle manure & $14.9 \pm 0.5 a b$ & $57.3 \pm 1.8 \mathrm{a}$ & $851 \pm 40 b$ & $19.8 \pm 0.3 b$ \\
\hline \multirow[t]{5}{*}{ Strickhof } & No Zn & $16.3 \pm 0.7 \mathrm{a}$ & $38.3 \pm 1.1 \mathrm{a}$ & $621 \pm 41 a$ & - \\
\hline & $\mathrm{ZnSO}_{4}$ & $16.2 \pm 0.4 \mathrm{a}$ & $40.6 \pm 0.4 \mathrm{bc}$ & $656 \pm 11 \mathrm{ab}$ & $12.1 \pm 0.8 \mathrm{a}$ \\
\hline & Sewage sludge & $16.6 \pm 0.2 \mathrm{a}$ & $39.7 \pm 0.4 \mathrm{ab}$ & $656 \pm 0.9 a b$ & $10.6 \pm 0.4 a$ \\
\hline & Poultry manure & $16.3 \pm 0.5 a$ & $42.1 \pm 0.9 c$ & $690 \pm 25$ bc & $10.8 \pm 1.4 \mathrm{a}$ \\
\hline & Cattle manure & $15.7 \pm 1.1 \mathrm{a}$ & $46.1 \pm 1.3 \mathrm{~d}$ & $726 \pm 31 c$ & $10.7 \pm 0.3 a$ \\
\hline \multirow[t]{3}{*}{ ANOVA } & Soil & 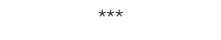 & 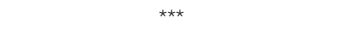 & 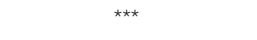 & $\star \star \star ~$ \\
\hline & Fertilizer & * & 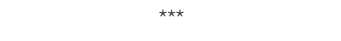 & 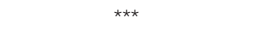 & * \\
\hline & Soil $\times$ Fertilizer & * & 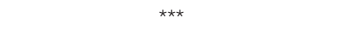 & $n s$ & 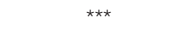 \\
\hline
\end{tabular}

Values represent the mean values of $n=4$ replicates \pm standard deviation. Zndffertavg values are corrected for the uptake of $Z n$ derived from the seed.

Zndffertavg was calculated as the average proportion of Zn uptake derived from the fertilizer at cuts 1-4.

For each soil, different letters in the same column indicate significant differences $(p<0.05)$ among treatments.

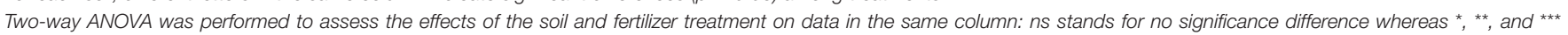
indicate significant differences at the probability level of 0.05, 0.01, and 0.001, respectively.

in the Heitenried soil that received no Zn. In the Strickhof soil, by contrast, no significant impact of the Zn-fertilizer additions was observed on the production of shoot dry matter. However, the addition of poultry and cattle manure increased the $\mathrm{Zn}$ concentration in the shoots by $10-20 \%$, compared with the no $\mathrm{Zn}$ treatment in the Strickhof soil. The highest shoot $\mathrm{Zn}$ concentration was observed in the cattle manure, followed by the poultry manure treatment, and the same hierarchy was found for the $\mathrm{Zn}$ uptake. A direct comparison of both soils revealed that the shoot dry weight was higher, whereas the $\mathrm{Zn}$ concentration and $\mathrm{Zn}$ uptake were lower in the Strickhof soil than in the Heitenried soil (Table 3).

\section{Fraction of Plant $\mathrm{Zn}$ Derived From Organic Fertilizers, Soils, and Seeds}

By labeling the soil available $\mathrm{Zn}$ pool with ${ }^{67} \mathrm{Zn}$, we could precisely calculate the contribution of $\mathrm{Zn}$ derived from organic fertilizers, soils, and seeds to the $\mathrm{Zn}$ uptake in the ryegrass shoots. In the Heitenried soil, most of the $\mathrm{Zn}$ in the shoots derived from the soil ( $Z n d f$ soil $l_{\text {avg }} ; 79-82 \%$ for fertilizer treatments) whereas about one fifth derived from the fertilizers (Zndffert $t_{\text {avg }} ; 17-20 \%$; Table 3). Zndffert $t_{\text {avg }}$ and the quantity of $\mathrm{Zn}$ that was transferred from the freshly applied fertilizers to the shoots (QZndffert sum $_{\text {) }}$ were the lowest with $\mathrm{ZnSO}_{4}$ and highest with the animal manures (Figure 1A). In addition, the quantity of $\mathrm{Zn}$ that was transferred from the soil to the ryegrass shoots $\left(Q Z n d f\right.$ soil $\left._{\text {sum }}\right)$ did not significantly differ among the treatments (Figure 1B). In the Strickhof soil, $86-88 \%$ of the plant $\mathrm{Zn}$ uptake derived from the soil whereas $11-12 \%$ derived from the fertilizers (Table 3, Figure 1). The contribution of $\mathrm{Zn}$ derived from freshly applied fertilizer to shoot $\mathrm{Zn}$ uptake $\left(\mathrm{ZNdffert}_{\mathrm{avg}}\right.$ and QZndffert $\left.\mathrm{sum}_{\text {sum }}\right)$ did not differ between treatments. In addition, QZndfsoil sum $_{\text {s. }}$ were not distinguishable between the fertilized and non-fertilized treatments (Figure 1B).

The stable isotope ${ }^{67} \mathrm{Zn}$ was further employed to precisely calculate the contribution of $\mathrm{Zn}$ from the ryegrass seeds. With the seeds, $44 \mu \mathrm{g} \mathrm{Zn} \mathrm{kg}{ }^{-1}$ soil was added to the soils. Given the values of QZndffert sum $_{\text {in }}$ the ryegrass shoots $(72-180 \mu \mathrm{g}$ $\mathrm{Zn} \mathrm{kg}{ }^{-1}$ soil), $\mathrm{Zn}$ derived from the seed could be an important third source and lead to an overestimated uptake of $\mathrm{Zn}$ derived from the fertilizer. In the no $\mathrm{Zn}$ treatment, the soil $\left({ }^{67} \mathrm{Zn}\right.$ labeled) and the seeds (non-labeled) were the only sources of $\mathrm{Zn}$ for the ryegrass shoots. For the first cut, the ${ }^{67} \mathrm{Zn}:{ }^{66} \mathrm{Zn}$ isotope ratios were significantly lower than for cuts $2-4$ in all treatments (Supplementary Figure S1). These results indicate that seed $\mathrm{Zn}$ was a substantial source of $\mathrm{Zn}$ in the initial growth phase of the ryegrass. Based on the ${ }^{67} \mathrm{Zn}:{ }^{66} \mathrm{Zn}$ isotope ratios in the no Zn treatment (Equation 4), we calculate that the seed $\mathrm{Zn}$ contributed to $1.64-2.25 \%$ of the total $\mathrm{Zn}$ uptake in the ryegrass shoot.

\section{Comparison of Plant Use Efficiency of Fertilizer Zn Obtained From Mass Balance and Isotopic Approaches}

The fate of $\mathrm{Zn}$ derived from freshly applied complex organic fertilizers in soil-plant systems can be assessed by calculating the recovery of fertilizer $\mathrm{Zn}$ in the plant. The recovery can be calculated with a mass-balance $A U E$ approach or with an isotope labeling approach $\left(Z_{n R e} c_{\text {sum; }}\right.$; Table 4). A direct comparison of the two methods revealed that AUE (2.3-9.7\%) was overall lower than $Z n R e c_{\text {sum }}$ (4.7-12.0\%). Meanwhile, the $A U E$ values 


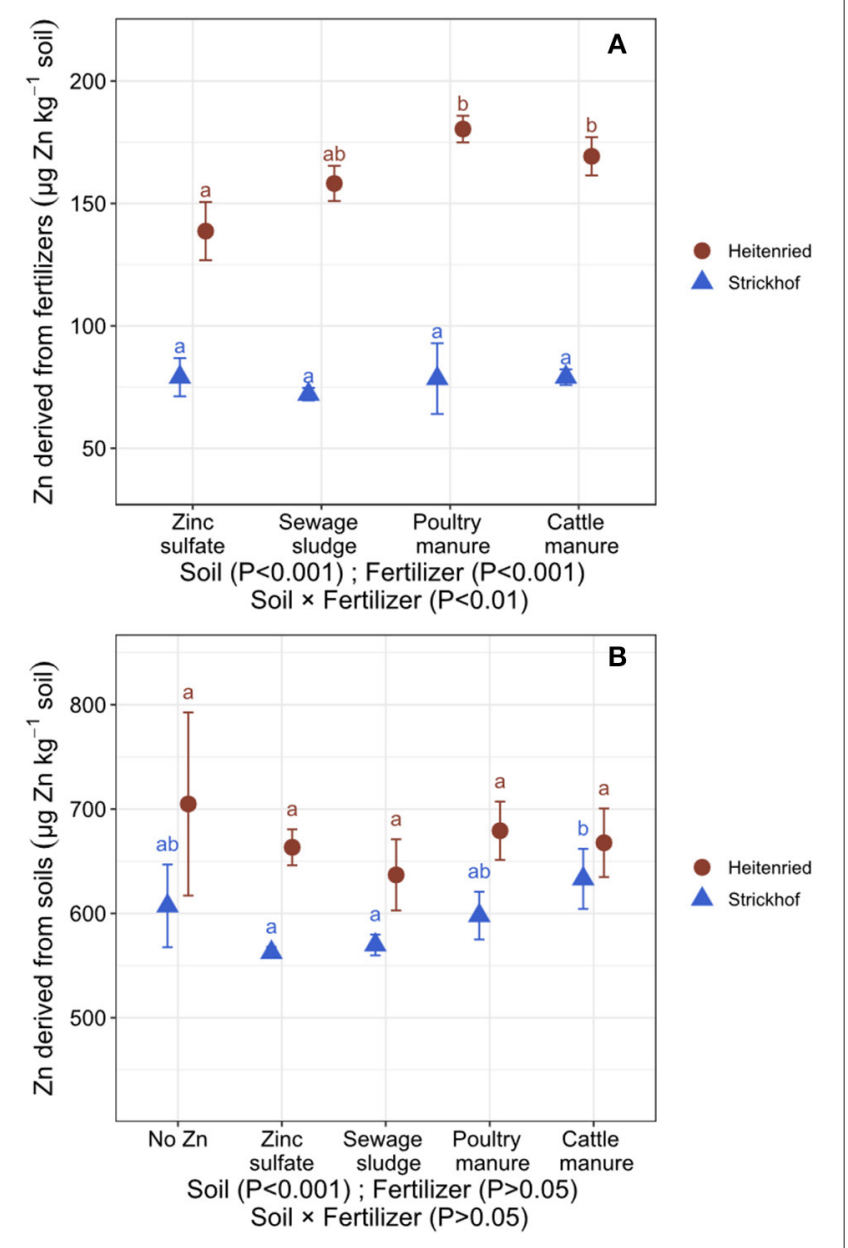

FIGURE 1 | Uptake of Zn derived from the Zn-containing fertilizers

(QZndffertsum; A) and soils (QZndfsoilsum; B) in the Italian ryegrass shoots (sum of 4 cuts) cultivated in a growth chamber and grown in soil from Heitenried $(\mathrm{pH}$ $=4.9$ ) and Strickhof $(\mathrm{pH}=7.7)$ without (no $\mathrm{Zn}$ ) and with the addition of distinct Zn-containing fertilizers. Data are average values \pm standard deviation (bars in the figures) calculated from $n=4$ replicates. QZndffert $t_{\text {sum }}$ values are corrected for the uptake of $\mathrm{Zn}$ derived from the seed. For each soil, different letters indicate significant differences $(p<0.05)$ among treatments. The effects of the soils and fertilizers tested by two-way ANOVA are shown at the bottom of each plot.

had a higher standard deviation $(\mathrm{SD}=0.6-3.3 \%)$ than the stable isotope $Z n R e c_{\text {sum }}$ results (SD $=0.2-1.0 \%$ ). The BlandAltman plot in Supplementary Figure S2 compares the AUE and $Z n R e c_{\text {sum }}$ that were obtained in this study. On average, AUE was $1.8 \%$ lower than $Z n R e c_{\text {sum }}$. This bias was $16.2 \%$ of the total range of $\mathrm{Zn}$ recovery calculated with the two methods. For each of the two soils, there was apparently a positive trend between the mean and difference of the results that were obtained with the two approaches. This trend indicates that the bias was not consistent and thus could not be corrected. The limit of agreement was between -6.1 and $2.5 \%$ based on the $95 \%$ confidence intervals (CI), meaning that $A U E$ could be $4.3 \%$ below or above $Z n R e c_{\text {sum }}$. Compared with the total range of $\mathrm{Zn}$ recovery calculated in
TABLE 4 | Recovery of Zn derived from the Zn-containing fertilizers in the Italian ryegrass shoot (sum of 4 cuts) cultivated in a growth chamber and grown in Heitenried soil $(\mathrm{pH}=4.9)$ and Strickhof soil $(\mathrm{pH}=7.7)$ amended with distinct $\mathrm{Zn}$-containing fertilizers, measured with the stable isotope approach ( $Z n R e c_{\text {sum }}$ ) and the AUE approach.

\begin{tabular}{|c|c|c|c|}
\hline \multirow[t]{2}{*}{ Soil } & \multirow[t]{2}{*}{ Treatment } & \multirow{2}{*}{$\begin{array}{c}Z n R e c_{\text {sum }} \\
\% \text { of } \mathrm{Zn} \text { input }\end{array}$} & \multirow{2}{*}{$\frac{A U E}{\% \text { of } \mathrm{Zn} \text { input }}$} \\
\hline & & & \\
\hline \multirow[t]{4}{*}{ Heitenried } & $\mathrm{ZnSO}_{4}$ & $9.8 \pm 0.8 a$ & $6.8 \pm 2.0 \mathrm{a}$ \\
\hline & Sewage sludge & $10.4 \pm 0.5 a b$ & $7.5 \pm 3.3 \mathrm{a}$ \\
\hline & Poultry manure & $12.0 \pm 0.4 \mathrm{~b}$ & $9.7 \pm 2.1 \mathrm{a}$ \\
\hline & Cattle manure & $10.9 \pm 0.5 \mathrm{ab}$ & $8.5 \pm 2.6 \mathrm{a}$ \\
\hline \multirow[t]{4}{*}{ Strickhof } & $\mathrm{ZnSO}_{4}$ & $5.6 \pm 0.5 a$ & $2.4 \pm 0.8 a$ \\
\hline & Sewage sludge & $4.7 \pm 0.2 a$ & $2.3 \pm 0.6 \mathrm{a}$ \\
\hline & Poultry manure & $5.2 \pm 1.0 \mathrm{a}$ & $4.6 \pm 1.7 \mathrm{ab}$ \\
\hline & Cattle manure & $5.1 \pm 0.2 \mathrm{a}$ & $6.7 \pm 2.0 \mathrm{~b}$ \\
\hline \multirow[t]{3}{*}{ ANOVA } & Soil & 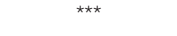 & 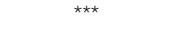 \\
\hline & Fertilizer & * & * \\
\hline & Soil $\times$ Fertilizer & ** & ns \\
\hline
\end{tabular}

Values represent the mean values of $n=4$ replicates \pm standard deviation. $Z n R e c_{s u m}$ values are corrected for the uptake of $Z n$ derived from the seed.

$Z n R e c_{s u m}$ was calculated as the uptake of $Z n$ derived from the fertilizer in all four cuts of ryegrass shoots divided by the total input of $Z n$ with the fertilizer.

Apparent use efficiency was calculated as the relative increase in the uptake of $\mathrm{Zn}$ in all four cuts between the fertilized and non-fertilized ryegrass divided by the total input of $\mathrm{Zn}$ with the fertilizer.

For each soil, different letters in the same column indicate significant differences $(p<0.05)$ among treatments.

Two-way ANOVA was performed to assess the effects of the soil and the fertilizer treatment on data in the same column: ns stands for no significance difference whereas ${ }^{*},{ }^{* *}$, and ${ }^{* \star *}$ indicate significant differences at the probability level of $0.05,0.01$, and 0.001 , respectively.

this study, the limit of agreement was $55 \%$ of the range of all $Z n R e c_{\text {sum }}$ values.

\section{Comparison of Zinc Isotope Ratios and Proportion of Fertilizer $\mathbf{Z n}$ in Plants and DGT Extracts}

The plants and the ${ }^{67} \mathrm{Zn}:{ }^{66} \mathrm{Zn}$ isotope ratios measured with the DGT were compared using a Bland-Altman plot (Figure 2). For the plant, only $\mathrm{Zn}$ in cut 4 was considered in this comparison, to minimize the influence of seed $\mathrm{Zn}$ (Supplementary Figure S1; Table S4). The ${ }^{67} \mathrm{Zn}:{ }^{66} \mathrm{Zn}$ ratios of the DGT extracts were on average 0.0018 units higher than those in the shoots. Meanwhile, there was no obvious relationship between the mean and the difference. The $95 \%$ confidence interval was \pm 0.0018 units, indicating that the ${ }^{67} \mathrm{Zn}:{ }^{66} \mathrm{Zn}$ isotope ratios measured in the DGT extracts can be higher or lower by up to 0.0018 units than those in the shoots without showing any significant statistical difference. Both the bias and the confidence interval account for $1.2 \%$ of the range of all the isotope ratios that were measured in this study.

The proportion of DGT-extracted $\mathrm{Zn}$ that derived from

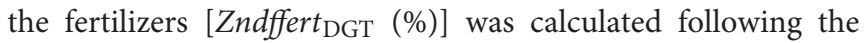
same principles as for the plant (Equation 5). In the equation, ${ }^{67} \mathrm{Zn}:{ }^{66} \mathrm{Zn}$ ratios measured in the DGT extracts were used instead of those in the plant, whereas the soil $\mathrm{Zn}$ isotope 


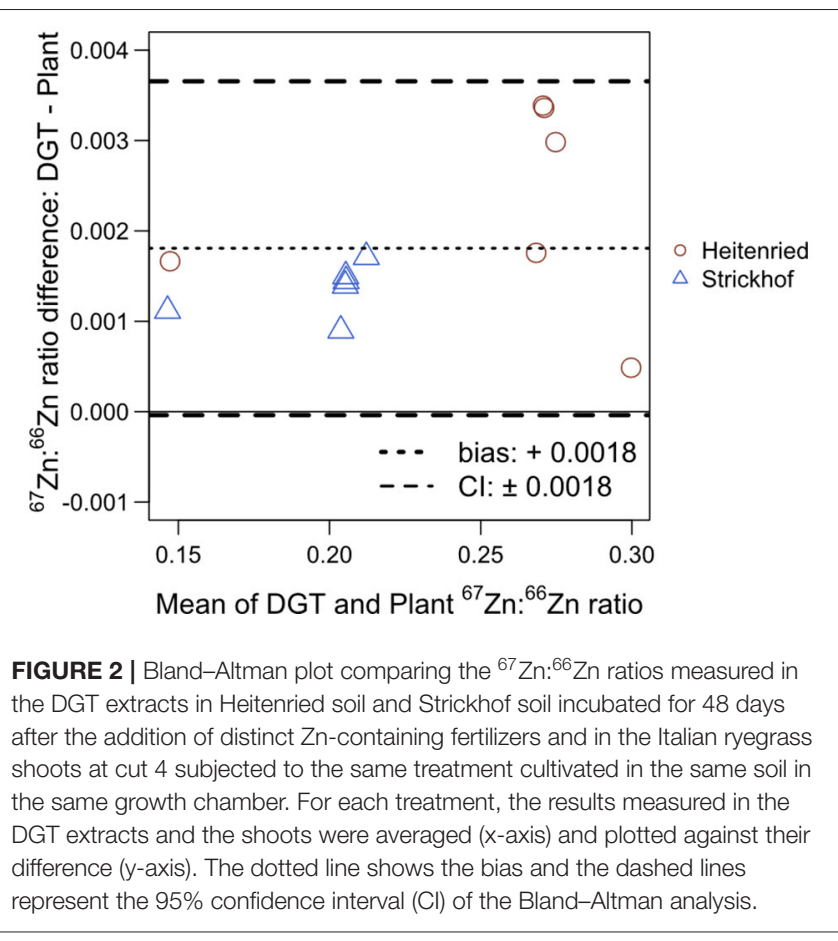

abundances of ${ }^{67} \mathrm{Zn}$ and ${ }^{66} \mathrm{Zn}$ were measured in the DGT extracts in the no $\mathrm{Zn}$ treatment instead of the abundances measured in the ryegrass shoots. In Figure 3, Zndffert ${ }_{\text {DGT }}$ values were compared with $Z_{n d f f e r t}$ values measured in the ryegrass shoots at cut 4 (Supplementary Table S3) through a Bland-

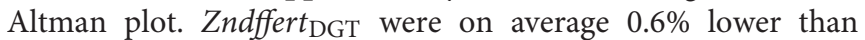
$Z_{n d f f e r t}$, which accounts for $6 \%$ of the total range of $Z n d f f e r t_{\text {DGT }}$ and Zndffert $_{4}$ values (10-20\%). Meanwhile, Zndffert DGT $_{\text {and }}$ Zndffert $_{4}$ were highly positively correlated in each of the soils $(p<0.05)$ and in both soils $(R=0.987 ; p<0.001$; Supplementary Figure S3).

\section{DISCUSSION}

\section{Contribution of Complex Organic Fertilizers to the Zinc Nutrition of Ryegrass}

In both soils, the addition of water-soluble $\mathrm{Zn}$ as $\mathrm{ZnSO}_{4}$ did not alter the shoot dry weight $\left(D W_{\text {sum }}\right)$, compared with the no $\mathrm{Zn}$ treatment (Table 3). These results suggest that the initial availability of $\mathrm{Zn}$ in the soil did not limit the plant biomass production. The $\mathrm{Zn}$ concentrations in the ryegrass shoots in the no $\mathrm{Zn}$ and $\mathrm{ZnSO}_{4}$ treatments ranged from 38 to $56 \mu \mathrm{g} \mathrm{Zn} \mathrm{g}$ DW, which indicates that the plants were neither $\mathrm{Zn}$ limited nor exposed to excess Zn (Broadley et al., 2007).

The higher soil $\mathrm{pH}$ in the alkaline Strickhof soil $(\mathrm{pH} 7.7)$ may have caused the overall higher shoot dry weight, lower $\mathrm{Zn}$ concentration and uptake, and lower QZndffert $t_{\text {sum }}$ and QZndfsoil sum $_{\text {san }}$ those in the acidic Heitenried soil ( $\left.\mathrm{pH} 4.9\right)$. For the higher shoot dry weight in the Strickhof soil, one explanation would be that the growth of Italian ryegrass was favored under neutral to alkaline soil conditions (Gregory and

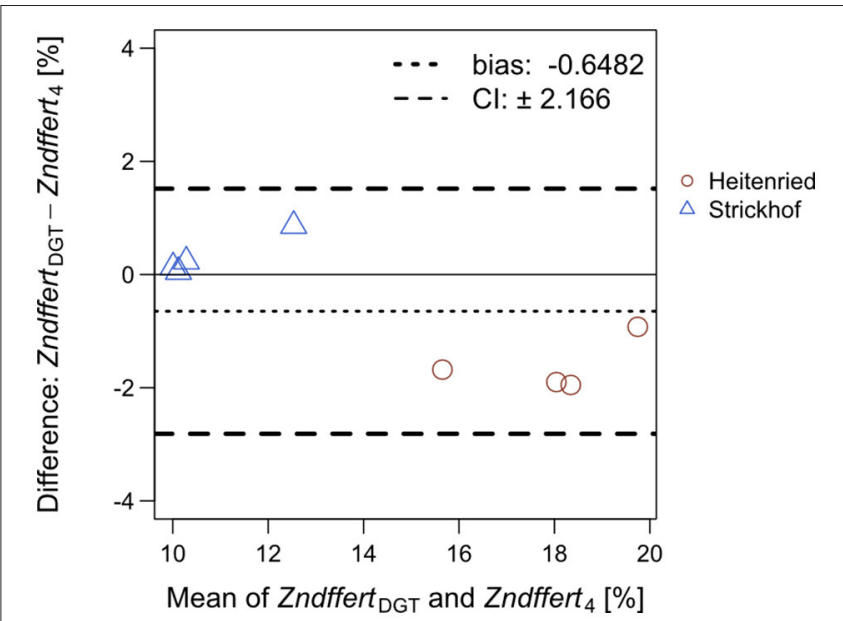

FIGURE 3 | Bland-Altman plot comparing the proportion of Zn derived from the $\mathrm{Zn}$-containing fertilizers in the DGT extracts (Zndffert DGT $_{\text {) }}$ and in Italian ryegrass shoots at cut $4\left(Z n d f f e r t_{4}\right)$ subjected to the same treatment in the same soil. For each treatment, the values of $Z_{n d f f e r} t_{\text {DGT }}$ and $Z_{n d f f e r} t_{4}$ were averaged ( $x$-axis) and plotted against their difference ( $y$-axis). The dotted line shows the bias and the dashed lines represent the 95\% confidence interval $(\mathrm{Cl})$ of the Bland-Altman analysis.

Nortcliff, 2013; CABI, 2020). The availability of $\mathrm{Zn}$ is higher in acidic than in alkaline soils, but also other soil properties such as total $\mathrm{Zn}$ concentration and soil carbonate concentration can affect Zn availability (Mertens and Smolders, 2013). The QZndffert $t_{\text {sum }}$ and total $\mathrm{Zn}$ uptake were higher in the acidic Heitenried compared with the alkaline Strickhof soil (Table 3). These results suggest that soil $\mathrm{Zn}$ had a minor impact on $\mathrm{Zn}$ plant uptake, since soil $\mathrm{Zn}$ was about two times as high in the Strickhof compared with the Heitenried soil (Table 1). The higher soil $\mathrm{pH}$, and likely the higher carbonate concentration, in the Strickhof soil may have reduced the solubility of $\mathrm{Zn}$ derived from the fertilizer and soil due to a stronger adsorption of $\mathrm{Zn}$ on negatively charged binding sites of the soil (Diesing et al., 2008; Imseng et al., 2019). The lower solubility of fertilizer $\mathrm{Zn}$ and soil $\mathrm{Zn}$ in the alkaline Strickhof soil may have further lowered the concentration and uptake of $\mathrm{Zn}$ in the ryegrass shoots.

The animal manures significantly increased the plant uptake of $\mathrm{Zn}$, compared with the no Zn treatment in both soils (Table 3). Our results show that the enhanced $\mathrm{Zn}$ uptake was related to higher dry matter production in the acidic Heitenried soil and to an increased shoot $\mathrm{Zn}$ concentration in the alkaline Strickhof soil. In the Heitenried soil, Zndffert avg $_{\text {and }}$ QZndffert sum $_{\text {were }}$ significantly higher with the application of the animal manures than with $\mathrm{ZnSO}_{4}$ (Table 3, Figure 1A). Since very similar quantities of $\mathrm{Zn}$ were added to the soils among the different fertilization treatments, these results suggest that the $\mathrm{Zn}$ in the animal manures was more available to the ryegrass than $\mathrm{ZnSO}_{4}$ over one growth cycle. However, the distinct $\mathrm{Zn}$ availabilities among the fertilizers did increase neither the $\mathrm{Zn}$ concentration nor the $\mathrm{Zn}$ uptake into the ryegrass (Table 3). Unlike in the Heitenried soil, some of the fertilizers increased the shoot $\mathrm{Zn}$ concentrations in the alkaline Strickhof soil (Table 3). The 
fertilization treatments had no significant effects on $Z_{n d f f e r t}{ }_{\mathrm{avg}}$ and QZndffert $t_{\text {sum }}$, which indicates similar availability of $\mathrm{Zn}$ derived from these fertilizers to the ryegrass in the Strickhof soil. These results suggest that the increased $\mathrm{Zn}$ concentration and/or $\mathrm{Zn}$ uptake in the ryegrass shoots with the addition of $\mathrm{ZnSO}_{4}$ and the animal manures are likely induced through the $\mathrm{Zn}$ addition with these fertilizers.

The addition of green manure to alkaline soils can solubilize $\mathrm{Zn}$ in the soil pool and increase the transfer of soil $\mathrm{Zn}$ to the plant (Aghili et al., 2014). This increase has been ascribed to changes in soil $\mathrm{pH}$ or water-soluble organic ligands that increase the solubility of $\mathrm{Zn}$ in the soils during the decomposition of green manures (Gramlich et al., 2013; Soltani et al., 2014). In this study, the $\mathrm{Zn}, \mathrm{C}$, and $\mathrm{N}$ inputs with the organic fertilizers (Table 2) were similar to those in Aghili et al. (2014). However, QZndfsoil sum $_{\text {sum }}$ did not differ between the fertilized and nonfertilized treatments (Figure 1B), indicating that a $\mathrm{Zn}$ solubilization in alkaline soils through organic fertilizer may depend on soil and fertilizer properties. The alkaline Strickhof soil contained about 100 times more $\mathrm{CaCO}_{3}$ compared with the soil used by Aghili et al. (2014; Table 1). The higher $\mathrm{CaCO}_{3}$ concentration in the Strickhof soil may have buffered soil acidification effects caused by the nitrification processes and bicarbonates production during fertilizer decomposition. In addition, the DTPA-extractable $\mathrm{Zn}$ in the soil used by Aghili et al. (2014) was around 10 times lower than in the soils used in this study (Table 1). Hence, in this study, water soluble ligands such as amino acids that were potentially produced during the decomposition of the fertilizers (Soltani et al., 2014) may have rather formed complexes with $\mathrm{Zn}$ that was already in the solution than with $\mathrm{Zn}$ that was tightly bound to the soil matrix.

Moreover, the main components of the green manure used by Aghili et al. (2014) and the organic fertilizer used in our study differed. Green manure contains fresh plant material whereas the complex organic fertilizers contain feces, inorganic components, and, in the animal manures, undigested plant residues (e.g., mature lignified plant material; Rose et al., 2015). These distinct forms of organic matter influence the decomposition rate (Thuriès et al., 2001) and decomposition products of the organic fertilizers (Ohno and Crannell, 1996), and therefore also likely the soil properties that control the solubility of $\mathrm{Zn}$. Unlike animal manure, green manure added to a soil might quickly release low-molecular weight ligands, which leads to a desorption of $\mathrm{Zn}$ from the soil surface (Ohno and Crannell, 1996; Thuriès et al., 2001; Soltani et al., 2014). Furthermore, in this study, the duration of the plant growth trial in the fertilized soils was 48 days which is much shorter than the 125 days in Aghili et al. (2014). In soils incubated with complex organic fertilizers, the decomposition of organic fertilizers could last for more than 3 months and result in reduced soil $\mathrm{pH}$ and increased soil $\mathrm{Zn}$ availability after 60 days of incubation (Tella et al., 2016). Together, an increase of the available $\mathrm{Zn}$ in alkaline soils upon the addition of organic fertilizer may depend on soil and fertilizer properties such as buffer capacity and the main components of organic fertilizer, and also the incubation time for the fertilizer in soils. Clearly, further studies are needed to identify major mechanisms and types of organic fertilizer that solubilize $\mathrm{Zn}$ in alkaline soils.

The result that $11-20 \%$ of the $\mathrm{Zn}$ in the plant derived from the fertilizers is at the lower end of the scale, compared with previous observations (Amer et al., 1980; McBeath et al., 2013; Aghili et al., 2014; McBeath and McLaughlin, 2014; Mattiello et al., 2021). Similar source-tracing studies revealed that $Z_{n d f f e r t} t_{\text {avg }}$ values ranged from 0.1 to $99 \%$ with a median of $19 \%$ (Dürr-Auster et al., 2019). The $Z$ ndffert $t_{\text {avg }}$ values are mainly related to the soil properties, $\mathrm{Zn}$ solubility, and quantity of $\mathrm{Zn}$ applied. The values $>50 \%$ are reported for the high input of water-soluble $\mathrm{Zn}$ or $\mathrm{Zn}$ oxides into sandy and calcareous soils, whereby the fertilizer $\mathrm{Zn}$ represents a major available source for plant $\mathrm{Zn}$ uptake (McBeath and McLaughlin, 2014). Lower values $(<50 \%)$ are either reported for soils with relatively small and large $\mathrm{Zn}$ available pools that received fertilizers with which $\mathrm{Zn}$ cannot be easily dissolved in soils, including Zn-coated fertilizers and organic fertilizers (e.g., plant residues; McBeath et al., 2013; Aghili et al., 2014; DürrAuster et al., 2019; Mattiello et al., 2021). The isotope results of our study indicated that the $\mathrm{Zn}$ derived from the complex organic fertilizers was equal or more available to the ryegrass than the soluble $\mathrm{ZnSO}_{4}$. Hence, the low $\mathrm{Zndffert}_{\mathrm{avg}}$ values found in this study might not be related to the low solubility of $\mathrm{Zn}$ in the complex organic fertilizers. As an alternative explanation, the DTPA-extractable $\mathrm{Zn}$ in the soil, which represents the soil available $\mathrm{Zn}$ pool, was 2.6-3.7 times higher than the $\mathrm{Zn}$ added with fertilizers (Tables 1, 2). This comparison indicates that the $\mathrm{Zn}$ added with the fertilizers was diluted with the soil available Zn pool, which could explain the comparably low contribution of $\mathrm{Zn}$ applied with fertilizer to plant $\mathrm{Zn}$.

\section{Most Zinc Freshly Applied With Complex Organic Fertilizers Remains in the Soil}

The relatively high confidence limits between $A U E$ and $Z n R e c_{\text {sum }}$ and the positive trend shown in the Bland-Altman plot (Supplementary Figure S2) indicate that the non-isotope AUE approach cannot be used interchangeably with the isotope approach. Meanwhile, the high standard deviation of $A U E$ (Table 4) illustrates that the stable isotope source-tracing technique is more precise than the AUE approach.

Previous studies have shown that complex organic fertilizer can be a main input into soils and potentially contribute to critical soil $\mathrm{Zn}$ accumulation. For example, in the Broadbalk long-term experiment, the concentration of $\mathrm{Zn}$ in the topsoil significantly increased with the application of farmyard manure over 160 years, as compared with the plot where no fertilizers were applied (Fan et al., 2008). Similarly, by determining the Zn fluxes at three Swiss meadow sites, animal manure application was recognized as the main $\mathrm{Zn}$ input into soils and significantly contributed to the current soil $\mathrm{Zn}$ accumulation in these grassland systems (Imseng et al., 2019). Such soil $\mathrm{Zn}$ accumulation could pose a threat to soil ecosystems, considering the potential toxicity of $\mathrm{Zn}$ on plants, invertebrates, and microbes (Påhlsson, 1989; Wang et al., 2007; Santorufo et al., 2012). The isotope results presented here provide complementary data to these soil $\mathrm{Zn}$ 
mass balances. The $Z n R e c_{\text {sum }}$ values ranged from 4.7 to $12.0 \%$ (Table 4), indicating that only a minor fraction of $\mathrm{Zn}$ derived from freshly applied fertilizer was transferred to the ryegrass shoots. Consequently, the majority of the fertilizer derived $\mathrm{Zn}$ remained in the soil after one crop cycle $(\sim 90 \%)$ and could be available for the next crop cycles and/or contribute to the buildup of a residual pool of $\mathrm{Zn}$ in a long run. Nevertheless, it is noteworthy that in this study, the plant growth trial lasted 48 days, and the results might be more representative of short crop cycles. As mentioned above, organic fertilizers could continuously decompose in soils for a longer time period, during which the desorption of $\mathrm{Zn}$ from Fe oxides in organic fertilizers could release available $\mathrm{Zn}$ to plants (Tella et al., 2016). Moreover, the quantity of the soil used for ryegrass cultivation was small, and the light intensity in the growth chamber was low, relative to those in the field. These conditions might limit the plant growth and total $\mathrm{Zn}$ uptake due to the pot-bound root system and the depressed photosynthesis efficiency (Poorter et al., 2012) and result in an underestimated $Z n R e c_{\text {sum }}$. Hence, the plant use efficiency of $\mathrm{Zn}$ derived from complex organic fertilizers remains to be tested for longer crop cycles, such as on perennial crops, under field conditions.

\section{Can DGT Be Used as a Proxy for Assessing the Proportion of $\mathrm{Zn}$ Derived From Fertilizers in Plants?}

Diffusive gradients in thin films technique is an established technique to assess the availability of soil $\mathrm{Zn}$ to plants (Cornu and Denaix, 2006; Degryse et al., 2009; Tandy et al., 2011). Here, we aimed to expand the scope of DGT by measuring isotope ratios in DGT extracts and thereby determine the contribution of soil and fertilizer $\mathrm{Zn}$ to the soluble $\mathrm{Zn}$ fraction in the soils. As shown in Figures 2 and 3, very similar isotope ratios of ${ }^{67} \mathrm{Zn}:{ }^{66} \mathrm{Zn}$ and Zndffert values were obtained in the DGT extracts and ryegrass shoots, revealing that the DGT and plant extracted $\mathrm{Zn}$ from the same pool in the soils. Hence, $Z_{n d f f e r t}$ DGT revealed the distinct impacts of $\mathrm{Zn}$-containing fertilizers and soil $\mathrm{pH}$ on the contribution of fertilizer $\mathrm{Zn}$ to the soil available $\mathrm{Zn}$ pool, which are the same as those investigated through the plant trial. These results suggest that, instead of ryegrass, DGT can be adequately employed to predict the relative contribution of fertilizer and soil sources to the available $\mathrm{Zn}$ pool in soils, which is energyand labor-saving as compared with plant cultivation. To our knowledge, this is the first application of DGT for $\mathrm{Zn}$ source tracing in soil-fertilizer systems.

\section{CONCLUSION}

Our study demonstrated that stable $\mathrm{Zn}$ isotope soil labeling can be used to precisely determine the contribution of complex organic fertilizer to the $\mathrm{Zn}$ nutrition of plants and to precisely determine the fate of $\mathrm{Zn}$ applied with fertilizer in soil-plant systems. Particularly, we showed that the largest fraction of $\mathrm{Zn}$ in the ryegrass shoot was derived from the soil (79-88\%), followed by the $\mathrm{Zn}$-containing fertilizer (11-20\%), and the seed $(<2.3 \%)$ after 48 days of growth. The plant recovery of $\mathrm{Zn}$ derived from freshly applied complex organic fertilizers was low (4.7-12\%), whereas the major fraction of fertilizer $\mathrm{Zn}$ remained in the soil ( $>88 \%$ ). These findings illustrate that complex organic fertilizer may contribute to the buildup of a $\mathrm{Zn}$ residual pool in the soil. In both the acidic Heitenried soil and the alkaline Strickhof, animal manures increased the plant uptake of $\mathrm{Zn}$ more effectively than the water-soluble $\mathrm{ZnSO}_{4}$. Meanwhile, our results indicate that $\mathrm{Zn}$ in the animal manure has an equal or even higher availability than $\mathrm{ZnSO}_{4}$ for the ryegrass grown in the two soils. Finally, this study indicates that the passive DGT sampler extracted $\mathrm{Zn}$ from the same soil pool as the ryegrass. The scope of DGT could be therefore extended to estimate the relative contribution of $\mathrm{Zn}$ fertilizers to the soil available $\mathrm{Zn}$ pool and therefore to plant nutrition.

\section{DATA AVAILABILITY STATEMENT}

The original contributions presented in the study are included in the article/Supplementary Materials, further inquiries can be directed to the corresponding authors.

\section{AUTHOR CONTRIBUTIONS}

B-FY wrote original draft, formal analyses, data curation, and visualization. TD-A involved in methodology, resources, validation, experiments, and data collection. EF conducted conceptualization, methodology, validation, data curation, writing review and editing, and funding acquisition. MW contributed to review and editing the manuscript and to investigations. All authors contributed to the article and approved the submitted version.

\section{FUNDING}

This study was funded by the Swiss State Secretariat for Education and Research within the framework of the COST (European Cooperation for Science and Technology) action Mineral-Improved Crop Production for Healthy Food and Feed (FA0905) with the Project Number C10.0085 and by the Group of Plant Nutrition.

\section{ACKNOWLEDGMENTS}

We thank the staff of the Group of Plant Nutrition at ETH Zurich for their support in the laboratory.

\section{SUPPLEMENTARY MATERIAL}

The Supplementary Material for this article can be found online at: https://www.frontiersin.org/articles/10.3389/fpls.2021. 730679/full\#supplementary-material 


\section{REFERENCES}

Aghili, F., Gamper, H. A., Eikenberg, J., Khoshgoftarmanesh, A. H., Afyuni, M., Schulin, R., et al. (2014). Green manure addition to soil increases grain zinc concentration in bread wheat. PLOS ONE 9:e101487. doi: 10.1371/journal.pone.0101487

Alloway, B. J. (2009). Soil factors associated with zinc deficiency in crops and humans. Environ. Geochem. Health 31, 537-548. doi: 10.1007/s10653-009-9255-4

Amer, F., Rezk, A. I., and Khalid, H. M. (1980). Fertilizer zinc efficiency in flooded calcareous soils. Soil Sci. Soc. Am. J. 44, 1025-1030. doi: 10.2136/sssaj1980.03615995004400050031x

Berenguer, P., Cela, S., Santiveri, F., Boixadera, J., and Lloveras, J. (2008). Copper and zinc soil accumulation and plant concentration in irrigated maize fertilized with liquid swine manure. Agron. J. 100, 1056-1061. doi: 10.2134/agronj2007.0321

Bland, J. M., and Altman, D. G. (1986). Statistical methods for assessing agreement between two methods of clinical measurement. Lancet 1, 307-310. doi: 10.1016/S0140-6736(86)90837-8

Bolan, N. S., Adriano, D. C., and Mahimairaja, S. (2004). Distribution and bioavailability of trace elements in livestock and poultry manure by-products. Crit. Rev. Environ. Sci. Technol. 34, 291-338. doi: 10.1080/10643380490434128

Bosshard, C., Oberson, A., Leinweber, P., Jandl, G., Knicker, H., Wettstein, H.R., et al. (2011). Characterization of fecal nitrogen forms produced by a sheep fed with ${ }^{15} \mathrm{~N}$ labeled ryegrass. Nutr. Cycl. Agroecosyst. 90, 355-368. doi: 10.1007/s10705-011-9437-1

Bracher, C., Frossard, E., Bigalke, M., Imseng, M., Mayer, J., and Wiggenhauser, M. (2021). Tracing the fate of phosphorus fertilizer derived cadmium in soilfertilizer-wheat systems using enriched stable isotope labeling. Environ. Pollut. 287, 117314. doi: 10.1016/j.envpol.2021.117314

Broadley, M. R., White, P. J., Hammond, J. P., Zelko, I., and Lux, A. (2007). Zinc in plants. New Phytol. 173, 677-702. doi: 10.1111/j.1469-8137.2007.01996.x

CABI (2020). "Lolium multiflorum," in Invasive Species Compendium (Wallingford, UK: CAB International).

Cornu, J.-Y., and Denaix, L. (2006). Prediction of zinc and cadmium phytoavailability within a contaminated agricultural site using DGT. Environ. Chem. 3, 61-64. doi: 10.1071/en05050

Degryse, F., Smolders, E., Zhang, H., and Davison, W. (2009). Predicting availability of mineral elements to plants with the DGT technique: a review of experimental data and interpretation by modelling. Environ. Chem. 6, 198-218. doi: 10.1071/En09010

Diesing, W., Sinaj, S., Sarret, G., Manceau, A., Flura, T., Demaria, P., et al. (2008). Zinc speciation and isotopic exchangeability in soils polluted with heavy metals. Eur. J. Soil Sci. 59, 716-729. doi: 10.1111/j.1365-2389.2008.01032.x

Dürr-Auster, T., Wiggenhauser, M., Zeder, C., Schulin, R., Weiss, D. J., and Frossard, E. (2019). The use of Q-ICPMS to apply enriched zinc stable isotope source tracing for organic fertilizers. Front. Plant Sci. 10:1382. doi: $10.3389 /$ fpls.2019.01382

Fan, M. S., Zhao, F. J., Fairweather-Tait, S. J., Poulton, P. R., Dunham, S. J., and McGrath, S. P. (2008). Evidence of decreasing mineral density in wheat grain over the last 160 years. J. Trace Elem. Med. Biol. 22, 315-324. doi: 10.1016/j.jtemb.2008.07.002

Frossard, E., Achat, D. L., Bernasconi, S. M., Bünemann, E. K., Fardeau, J.-C., Jansa, J., et al. (2011). "The use of tracers to investigate phosphate cycling in soilplant systems," in Phosphorus in Action: Biological Processes in Soil Phosphorus Cycling, eds E. Bünemann, A. Oberson, and E. Frossard (Berlin, Heidelberg: Springer), 59-91.

Frossard, E., Demaria, P., Sinaj, S., and Schärer, M. (2014). A flow-through reactor to assess potential phosphate release from agricultural soils. Geoderma 219-220, 125-135. doi: 10.1016/j.geoderma.2013.12.015

Gramlich, A., Tandy, S., Frossard, E., Eikenberg, J., and Schulin, R. (2013). Availability of zinc and the ligands citrate and histidine to wheat: does uptake of entire complexes play a role? J. Agr. Food Chem. 61, 10409-10417. doi: $10.1021 /$ jf $401117 \mathrm{~d}$

Gregory, P. J., and Nortcliff, S. (2013). Soil Conditions and Plant Growth. New York: John Wiley and Sons.

Hodomihou, N. R., Feder, F., Legros, S., Formentini, T. A., Lombi, E., and Doelsch, E. (2020). Zinc speciation in organic waste drives its fate in amended soils. Environ. Sci. Technol. 54, 12034-12041. doi: 10.1021/acs.est.0c 02721

Hooda, P. S., Zhang, H., Davison, W., and Edwards, A. C. (1999). Measuring bioavailable trace metals by diffusive gradients in thin films (DGT): soil moisture effects on its performance in soils. Eur. J. Soil Sci. 50, 285-294. doi: 10.1046/j.1365-2389.1999.00226.x

Imseng, M., Wiggenhauser, M., Muller, M., Keller, A., Frossard, E., Wilcke, W., et al. (2019). The fate of $\mathrm{Zn}$ in agricultural soils: a stable isotope approach to anthropogenic impact, soil formation, and soil-plant cycling. Environ. Sci. Technol. 53, 4140-4149. doi: 10.1021/acs.est.8b03675

IUSS Working Group WRB (2015). World Reference Base for Soil Resources 2014, Update 2015 International Soil Classification System for Naming Soils and Creating Legends for Soil Maps. World Soil Resources Reports No. 106. IUSS Working Group WRB.

Mäder, P., Fliessbach, A., Dubois, D., Gunst, L., Fried, P., and Niggli, U. (2002). Soil fertility and biodiversity in organic farming. Science 296:1694. doi: $10.1126 /$ science. 1071148

Mattiello, E. M., Cancellier, E. L., Da Silva, R. C., Degryse, F., Baird, R., and McLaughlin, M. J. (2021). Efficiency of soil-applied ${ }^{67} \mathrm{Zn}$-enriched fertiliser across three consecutive crops. Pedosphere 31, 531-537. doi: 10.1016/s1002-0160(20)60044-3

McBeath, T. M., and McLaughlin, M. J. (2014). Efficacy of zinc oxides as fertilisers. Plant Soil 374, 843-855. doi: 10.1007/s11104-013-1919-2

McBeath, T. M., McLaughlin, M. J., Kirby, J. K., and Degryse, F. (2013). A stableisotope methodology for measurement of soil-applied zinc-fertilizer recovery in durum wheat (Triticum durum). J. Plant Nutr. Soil Sci. 176, 756-763. doi: 10.1002/jpln.201200305

Meija, J., Coplen, T. B., Berglund, M., Brand, W. A., De Bièvre, P., Gröning, M., et al. (2016). Atomic weights of the elements 2013 (IUPAC Technical Report). Pure Appl. Chem. 88, 265-291. doi: 10.1515/pac-2015-0305

Mertens, J., and Smolders, E. (2013). "Zinc," in Heavy Metals in Soils: Trace Metals and Metalloids in Soils and Their Bioavailability, ed B. J. Alloway (Dordrecht: Springer Netherlands), 465-493.

Nicholson, F. A., Smith, S. R., Alloway, B. J., Carlton-Smith, C., and Chambers, B. J. (2003). An inventory of heavy metals inputs to agricultural soils in England and Wales. Sci. Total Environ. 311, 205-219. doi: 10.1016/s0048-9697(03)00139-6

Ohno, T., and Crannell, B. S. (1996). Green and animal manure-derived dissolved organic matter effects on phosphorus sorption. J. Environ. Qual. 25, 1137-1143. doi: 10.2134 /jeq1996.00472425002500050029x

Påhlsson, A.-M. B. (1989). Toxicity of heavy metals $(\mathrm{Zn}, \mathrm{Cu}, \mathrm{Cd}, \mathrm{Pb})$ to vascular plants. Water Air Soil Pollut. 47, 287-319. doi: 10.1007/BF00279329

Poorter, H., J, B.H., van Dusschoten, D., Climent, J., and Postma, J. A. (2012). Pot size matters: a meta-analysis of the effects of rooting volume on plant growth. Funct Plant Biol. 39, 839-850. doi: 10.1071/FP12049

Pypers, P., Van Loon, L., Diels, J., Abaidoo, R., Smolders, E., and Merckx, R. (2006). Plant-available P for maize and cowpea in P-deficient soils from the Nigerian Northern Guinea savanna-comparison of $E$ - and L-values. Plant Soil 283, 251-264. doi: 10.1007/s11104-006-0016-1

Rose, C., Parker, A., Jefferson, B., and Cartmell, E. (2015). The characterization of feces and urine: a review of the literature to inform advanced treatment technology. Crit. Rev. Environ. Sci. Technol. 45, 1827-1879. doi: 10.1080/10643389.2014.1000761

Santorufo, L., Van Gestel, C. A., Rocco, A., and Maisto, G. (2012). Soil invertebrates as bioindicators of urban soil quality. Environ. Pollut. 161, 57-63. doi: 10.1016/j.envpol.2011.09.042

Schindler, F. V., and Knighton, R. E. (1999). Fate of fertilizer nitrogen applied to corn as estimated by the isotopic and difference methods. Soil Sci. Soc. Am. J. 63, 1734-1740. doi: 10.2136/sssaj1999.6361734x

Signorell, C., Zimmermann, M. B., Cakmak, I., Wegmuller, R., Zeder, C., Hurrell, R., et al. (2019). Zinc absorption from agronomically biofortified wheat is similar to post-harvest fortified wheat and is a substantial source of bioavailable zinc in humans. J. Nutr. 149, 840-846. doi: 10.1093/jn/nxy328

Sinaj, S., Dubois, A., and Frossard, E. (2004). Soil isotopically exchangeable zinc: a comparison between $E$ and $L$ values. Plant Soil 261, 17-28. doi: 10.1023/B:Plso.0000035577.64548.45

Soltani, S., Khoshgoftarmanesh, A. H., Afyuni, M., Shrivani, M., and Schulin, R. (2014). The effect of preceding crop on wheat grain zinc concentration and its relationship to total amino acids and dissolved organic carbon in rhizosphere 
soil solution. Biol. Fertil. Soils. 50, 239-247. doi: 10.1007/s00374-0130851-1

Tandy, S., Mundus, S., Yngvesson, J., de Bang, T. C., Lombi, E., Schjoerring, J. K., et al. (2011). The use of DGT for prediction of plant available copper, zinc and phosphorus in agricultural soils. Plant Soil 346, 167-180. doi: 10.1007/s11104-011-0806-y

Tella, M., Bravin, M. N., Thuriès, L., Cazevieille, P., Chevassus-Rosset, C., Collin, B., et al. (2016). Increased zinc and copper availability in organic waste amended soil potentially involving distinct release mechanisms. Environ. Pollut. 212, 299-306. doi: 10.1016/j.envpol.2016.01.077

Thuriès, L., Pansu, M., Feller, C., Herrmann, P., and Rémy, J. C. (2001). Kinetics of added organic matter decomposition in a Mediterranean sandy soil. Soil Biol. Biochem. 33, 997-1010. doi: 10.1016/S0038-0717(01) 00003-7

Wang, Y.-P., Shi, J.-Y., Qi, L., Chen, X.-C., and Chen, Y.-X. (2007). Heavy metal availability and impact on activity of soil microorganisms along a $\mathrm{Cu} / \mathrm{Zn}$ contamination gradient. J. Environ. Sci. 19, 848-853. doi: 10.1016/S1001-0742(07)60141-7
Conflict of Interest: The authors declare that the research was conducted in the absence of any commercial or financial relationships that could be construed as a potential conflict of interest.

Publisher's Note: All claims expressed in this article are solely those of the authors and do not necessarily represent those of their affiliated organizations, or those of the publisher, the editors and the reviewers. Any product that may be evaluated in this article, or claim that may be made by its manufacturer, is not guaranteed or endorsed by the publisher.

Copyright (c) 2021 Yan, Dürr-Auster, Frossard and Wiggenhauser. This is an openaccess article distributed under the terms of the Creative Commons Attribution License (CC BY). The use, distribution or reproduction in other forums is permitted, provided the original author(s) and the copyright owner(s) are credited and that the original publication in this journal is cited, in accordance with accepted academic practice. No use, distribution or reproduction is permitted which does not comply with these terms. 